\title{
MATERLALS
}

\section{Morphological Data on the Skeletons of the KANASEKI-Family}

\author{
Naomi DoI \\ Department of Anatomy, Faculty of Medicine, \\ Kyushu University
}

\begin{abstract}
Metric and non-metric data on the skeletons of the KANASEKI-family, the late Dr. T. KANASEKI and his father, Mr. K. KANASEKI, are presented. Photographs of bones are also shown in plates.
\end{abstract}

Key Words Craniometry, Osteometry, Nonmetric variants, The KANASEKI-family

The late Dr. Takeo KANASEKI, a famous physical anthropologist in Japan, was born in Kagawa Prefecture on February 18, 1897, and died in 1983 at the age of 86 . When he was a professor of Kyushu University (1950-1960), he excavated plenty of Yayoi sites (Doigahama, Mitsu-Nagata, Hirota etc.), and collected many Yayoi skeletons. By examining these skeletons, KANASEKI (1966) established a new theory on the origin of the Japanese, "hybridization theory", that the people who had high stature and a primitive rice agriculture migrated from the Korean Peninsula to the northern part of Kyushu at the beginning of the Yayoi period (3C.
B.C.-3C. A.D).

Dr. KANASEKI's father, Mr. Kisaburo KANASEKI, was born in Kagawa Prefecture, 1859 , and died in 1943 at the age of 84 . He was an architect.

By Dr. KANASEKI's will, their skeletons were offered and kept in the Department of Anatomy, Faculty of Medicine, Kyushu University. These skeletons were measured chiefly according to MARTIN und SALLER (1957) and to YAMAGUCHI $(1973,1980)$ for facial flatness measurements. Nonmetric variants were observed as described by BERRY and BERRY (1967), DoDo $(1974,1975)$ and FINNEGAN (1978). 
Table 1. Measurements (in $\mathrm{mm}$ ) and indices of the KANASEKI-family; Cranium

\begin{tabular}{|c|c|c|c|}
\hline \multicolumn{2}{|c|}{ Item with MARTIN's number } & \multirow{2}{*}{$\begin{array}{c}\begin{array}{l}\text { K. KANASEKI } \\
\text { (father) }\end{array} \\
184\end{array}$} & \multirow{2}{*}{$\begin{array}{c}\begin{array}{c}\text { T. KANASEK } \\
\text { (son) }\end{array} \\
188\end{array}$} \\
\hline 1 & Max. cranial 1. & & \\
\hline 5 & Naso-basilar 1. & 104 & 108 \\
\hline 8 & Max. cranial b. & 138 & 144 \\
\hline 9 & Min. front. b. & 89 & 89 \\
\hline 11 & Biauricular b. & 126 & 130 \\
\hline 12 & Max. occip. b. & 105 & 106 \\
\hline 7 & L. of for. magnum & 37 & 35 \\
\hline 16 & B. of for. magnum & 28 & 27 \\
\hline 17 & Basi-bregmat. h. & 144 & 146 \\
\hline 23 & Horiz. circumference & 516 & 526 \\
\hline 24 & Transv. arc & 326 & 322 \\
\hline 25 & Medio-sagit. arc & 382 & 387 \\
\hline 26 & Frontal arc & 125 & 138 \\
\hline 27 & Parietal arc & 138 & 124 \\
\hline 28 & Occipital arc & 119 & 125 \\
\hline 29 & Frontal chord & 112 & 120 \\
\hline 30 & Parietal chord & 122 & 114 \\
\hline 31 & Occipital chord & 99 & 103 \\
\hline H.VRR & Vertex rad. & 132 & 128 \\
\hline H.NAR & Nasion rad. & 98 & 99 \\
\hline H.SSR & Subsp. rad. & 103 & 96 \\
\hline 40 & Basi-alveol. 1. & - & $(95)$ \\
\hline 43 & Upper facial b. & 107 & 108 \\
\hline 44 & Biorbital b. & 101 & 102 \\
\hline 45 & Bizygomatic b. & 136 & 140 \\
\hline 46 & Middle facial $\mathrm{b}$. & 107 & 107 \\
\hline 50 & Ant. interorbit. b. & 21 & 26 \\
\hline \multirow[t]{2}{*}{51} & Orbital b. (r) & 43 & 43 \\
\hline & Orbital b. (l) & 43 & 42 \\
\hline \multirow[t]{2}{*}{52} & Orbital h. (r) & 35 & 37 \\
\hline & Orbital h. (l) & 34 & 36 \\
\hline 54 & Nasal b. & 26 & 29 \\
\hline 55 & Nasal h. & 53 & 55 \\
\hline 57 & Min. b. of nasal bone & 8 & 10 \\
\hline $8 / 1$ & Cranial index & 75.0 & 76.6 \\
\hline $17 / 1$ & Length-height i. & 78.3 & 77.7 \\
\hline $17 / 8$ & Breadth-height i. & 104.3 & 101.4 \\
\hline \multirow[t]{2}{*}{$52 / 51$} & Orbital i. (r) & 81.4 & 86.0 \\
\hline & Orbital i. (l) & 79.1 & 85.7 \\
\hline $54 / 55$ & Nasal i. & 49.1 & 52.7 \\
\hline
\end{tabular}


Table 1. (continued)

\begin{tabular}{|c|c|c|c|}
\hline \multicolumn{2}{|c|}{ Item with MARTIN's number } & \multirow{2}{*}{$\begin{array}{l}\begin{array}{l}\text { K. KANASEKI } \\
\text { (father) }\end{array} \\
-\end{array}$} & \multirow{2}{*}{$\begin{array}{c}\begin{array}{c}\text { T. KANASEKI } \\
\text { (son) }\end{array} \\
(69)\end{array}$} \\
\hline 61 & Maxillo-alveol. b. & & \\
\hline 65 & Bicondylar b. & 125 & 125 \\
\hline 66 & Bigonial $b$. & 108 & 102 \\
\hline 68 & Mandibular 1 & 73 & 70 \\
\hline $68(1)$ & Max. proj. 1. of mandible & 105 & 106 \\
\hline \multirow[t]{2}{*}{70} & H. of ascend. ramus (r) & 64 & 60 \\
\hline & H. of ascend. ramus (l) & 64 & 60 \\
\hline \multirow[t]{2}{*}{$70 \mathrm{a}$} & Proj. 1. of the ramus (r) & 54 & 49 \\
\hline & Proj. 1. of the ramus (l) & 54 & 50 \\
\hline \multirow[t]{2}{*}{71} & B. of ascend. ramus (r) & 34 & 31 \\
\hline & B. of ascend. ramus (l) & 37 & 33 \\
\hline \multirow[t]{2}{*}{$71 / 70$} & I. of ascend. ramus (r) & 53.1 & 51.7 \\
\hline & I. of ascend. ramus (l) & 57.8 & 55.0 \\
\hline \multicolumn{4}{|c|}{ Facial flatness } \\
\hline & Frontal chord & 107 & 108 \\
\hline & Frontal subtense & 19.7 & 19.8 \\
\hline & Frontal index & 18.4 & 18.3 \\
\hline & Simotic chord & 7.8 & 10.3 \\
\hline & Simotic subtense & 2.3 & 3.4 \\
\hline & Simotic index & 29.5 & 33.0 \\
\hline & Zygomaxillary chord & 109 & 109 \\
\hline & Zygomaxillary subtense & 26.3 & 26.3 \\
\hline & Zygomaxillary index & 24.1 & 24.1 \\
\hline
\end{tabular}


Table 2. Measurements (in $\mathrm{mm}$ ) and indices of the KANASEKI-family; Clavicle and scapula

\begin{tabular}{|c|c|c|c|c|c|}
\hline \multirow[t]{2}{*}{ Item } & \multirow[t]{2}{*}{ with MARTIN's number } & \multicolumn{2}{|c|}{$\begin{array}{l}\text { K. KANASEKI } \\
\text { (father) }\end{array}$} & \multicolumn{2}{|c|}{$\begin{array}{c}\text { T. KANASEK } \\
\text { (son) }\end{array}$} \\
\hline & & $\mathrm{r}$ & 1 & $\mathrm{r}$ & 1 \\
\hline & Clavicle & & & & \\
\hline 1 & Max. length & - & - & 142 & 148 \\
\hline 2 & Height of curv. & 7 & 7 & 12 & 7 \\
\hline $2 \mathrm{a}$ & Height of curv. of shaft & - & 32 & 36 & 31 \\
\hline $2(1)$ & Height of curv. of acrom. & - & 32 & 34 & 35 \\
\hline 3 & Length of cord of curv. & 90 & 93 & 102 & 101 \\
\hline 4 & Vert. diam. of mid-shaft & 11 & 11 & 12 & 11 \\
\hline 5 & Sagit. diam. of mid-shaft & 16 & (15) & 15 & 15 \\
\hline 6 & Circumf. of mid-shaft & 44 & $(43)$ & 44 & 42 \\
\hline $4 / 5$ & Index of mid-shaft & 68.8 & (73.3) & 80.0 & 73.3 \\
\hline \multirow[t]{2}{*}{$6 / 1$} & L-T index & - & - & 31.0 & 28.4 \\
\hline & Scapula & & & & \\
\hline 1 & Anatomical width & 153 & 148 & 155 & 155 \\
\hline 2 & Anatomical length & 102 & 101 & 99 & 99 \\
\hline $2 a$ & Length of scapula & 112 & 110 & 110 & 112 \\
\hline 3 & Length of axill. margin & 120 & 123 & 128 & 130 \\
\hline 4 & Length of sup. margin & 85 & 82 & 81 & 86 \\
\hline 5 & Proj. 1. of infrasp. fossa & 111 & 108 & 105 & 108 \\
\hline $5 a$ & Anat. 1. of infrasp. fossa & 115 & 111 & 108 & 110 \\
\hline 6 & Proj. 1. of suprasp. fossa & 46 & 43 & 50 & 48 \\
\hline $6 a$ & Anat. 1. of suprasp. fossa & 50 & 47 & 58 & 54 \\
\hline 7 & Proj. l. of spine & 137 & 130 & 133 & 135 \\
\hline 8 & Length of spine base & 90 & 88 & 85 & 85 \\
\hline 9 & Max. width of acromion & 27 & 26 & 30 & 30 \\
\hline 10 & Max. length & 44 & 43 & 46 & 45 \\
\hline 11 & Max. 1. of corac. proc. & 46 & 47 & 46 & 44 \\
\hline 12 & L. of glenoid cavity & 43 & 41 & 42 & 42 \\
\hline 13 & W. of glenoid cavity & 33 & 32 & 34 & 30 \\
\hline 14 & Depth of glenoid cavity & 6 & 6 & 5 & 5 \\
\hline 15 & Angle between L-W axis & 95 & 91 & 89 & 91 \\
\hline 16 & Axillo-spinal angle & 50 & 45 & 43 & 43 \\
\hline 17 & Axillo-glenoid angle & 129 & 132 & 121 & 126 \\
\hline 19 & Spino-infrasp. angle & 70 & 74 & 75 & 76 \\
\hline 20 & Spino-suprasp. angle & 59 & 56 & 61 & 66 \\
\hline 21 & Spino-glenoid angle & 77 & 85 & 78 & 83 \\
\hline $2 / 1$ & W-L index & 66.7 & 68.2 & 63.9 & 63.9 \\
\hline $6 / 2$ & Supraspin. index & 45.1 & 42.6 & 50.5 & 48.5 \\
\hline $13 / 12$ & L-W index of glen. cav. & 76.7 & 78.0 & 81.0 & 71.4 \\
\hline
\end{tabular}


Table 3. Measurements (in $\mathrm{mm}$ ) and indices of the KANASEKI-family; Humerus, radius and ulna

\begin{tabular}{|c|c|c|c|c|c|}
\hline \multirow[t]{2}{*}{ Item } & \multirow[t]{2}{*}{ with MARTIN's number } & \multicolumn{2}{|c|}{$\begin{array}{l}\text { K. KANASEKI } \\
\text { (father) }\end{array}$} & \multicolumn{2}{|c|}{$\begin{array}{c}\text { T. KANASEKI } \\
\text { (son) }\end{array}$} \\
\hline & & $\mathrm{r}$ & 1 & $\mathbf{r}$ & 1 \\
\hline & Humerus & & & & \\
\hline 1 & Max. length & 303 & - & 305 & 302 \\
\hline 2 & Total length & 298 & - & 303 & 299 \\
\hline 3 & Upper epiphisial width & 50 & - & 52 & 50 \\
\hline 4 & Bicondylar width & 63 & 61 & 60 & 59 \\
\hline 5 & Max. diam. of mid-shaft & 27 & (27) & 26 & 25 \\
\hline 6 & Min. diam. of mid-shaft & 21 & (21) & 22 & 20 \\
\hline 7 & Least circumf. of shaft & 70 & 71 & 72 & 68 \\
\hline $7 a$ & Circumf. of mid-shaft & 79 & (78) & 77 & 74 \\
\hline 8 & Circumf. of head & 140 & - & 142 & 141 \\
\hline 9 & Transv. diam. of head & 43 & - & 44 & 42 \\
\hline 10 & Sagit. diam. of head & 46 & - & 46 & 45 \\
\hline 11 & Width of trochlea & 27 & 27 & 25 & 25 \\
\hline 13 & D-V diam. of trochlea & 28 & 28 & 29 & 27 \\
\hline $6 / 5$ & Index of cross-sec. & 77.8 & $(77.8)$ & 84.6 & 80.0 \\
\hline \multirow[t]{2}{*}{$7 / 1$} & L-T index & 23.1 & - & 23.6 & 22.5 \\
\hline & Radius & & & & \\
\hline 1 & Max. length & 233 & 232 & 232 & 228 \\
\hline 2 & Functional length & 218 & 217 & 215 & 212 \\
\hline 3 & Least circumference & 46 & 45 & 42 & 42 \\
\hline 4 & Transv. diam. of shaft & 19 & 19 & 19 & 19 \\
\hline $4 a$ & Transv. diam. of mid-shaft & 18 & 18 & 17 & 16 \\
\hline $4(1)$ & Transv. diam. of capit. & 25 & - & 22 & 21 \\
\hline $4(2)$ & Transv. diam. of neck & 16 & - & 13 & 14 \\
\hline 5 & D-V diam. of shaft & 14 & 14 & 13 & 13 \\
\hline $5 a$ & D-V diam. of mid-shaft & 13 & 13 & 13 & 13 \\
\hline $5(5)$ & Circumf. of mid-shaft & 52 & 50 & 48 & 47 \\
\hline $5(6)$ & Width of lower epiph. & 38 & 36 & 34 & 34 \\
\hline $3 / 2$ & L-T index & 21.1 & 20.7 & 19.5 & 19.8 \\
\hline $5 / 4$ & Index of cross-sec. & 73.7 & 73.7 & 68.4 & 68.4 \\
\hline \multirow[t]{2}{*}{$5 a / 4 a$} & Index of cross-sec. & 72.2 & 72.2 & 76.5 & 81.3 \\
\hline & Ulna & & & & \\
\hline 1 & Max. length & 252 & 251 & 251 & 249 \\
\hline 2 & Physiological length & 222 & 218 & 220 & 218 \\
\hline 3 & Least circumf. of shaft & 43 & 43 & 40 & 39 \\
\hline $5(1)$ & H. of upp. art. surface & 43 & 42 & 44 & 43 \\
\hline $5(2)$ & H. of hum. art. surface & 33 & 34 & 34 & 33 \\
\hline 6 & Width of olecranon & 29 & 28 & 29 & 26 \\
\hline 7 & D-V diam. of olecranon & 27 & 26 & 29 & 26 \\
\hline 8 & Height of olecranon & 20 & 20 & 24 & 24 \\
\hline 11 & D-V diam. of shaft & 14 & 14 & 15 & 13 \\
\hline 12 & Transv. diam. of shaft & 21 & 19 & 18 & 17 \\
\hline $3 / 2$ & L-T index & 19.4 & 19.7 & 18.2 & 17.9 \\
\hline $11 / 12$ & Index of cross-sec. & 66.7 & 73.7 & 83.3 & 76.5 \\
\hline
\end{tabular}


Table 4. Measurements (in $\mathrm{mm}$ ) and indices of the KANASEKI-family; Pelvis and patella

\begin{tabular}{|c|c|c|c|c|c|}
\hline \multirow[t]{2}{*}{ Item } & \multirow[t]{2}{*}{ with MARTIN's number } & \multicolumn{2}{|c|}{$\begin{array}{l}\text { K. KANASEKI } \\
\text { (father) }\end{array}$} & \multicolumn{2}{|c|}{$\begin{array}{l}\text { T. KANASEKI } \\
\text { (son) }\end{array}$} \\
\hline & & r & 1 & $\mathrm{r}$ & 1 \\
\hline & Pelvis & & & & \\
\hline 1 & Height of pelvis & 210 & 209 & 210 & 208 \\
\hline 2 & Max. width of pelvis & \multicolumn{2}{|c|}{266} & \multicolumn{2}{|c|}{267} \\
\hline 3 & Out. sagit. diam. of pelvis & \multicolumn{2}{|c|}{155} & \multicolumn{2}{|c|}{165} \\
\hline 4 & Depth of innominate & 172 & 176 & 178 & 178 \\
\hline 5 & Bi-ant. sup. sp. width & \multicolumn{2}{|c|}{216} & \multicolumn{2}{|c|}{218} \\
\hline 6 & Bi-post. sup. sp. width & \multicolumn{2}{|c|}{70} & \multicolumn{2}{|c|}{69} \\
\hline 7 & Bi-acetabular width & \multicolumn{2}{|c|}{110} & \multicolumn{2}{|c|}{117} \\
\hline 8 & Bi-isch. sp. width & \multicolumn{2}{|c|}{79} & \multicolumn{2}{|c|}{90} \\
\hline 9 & Height of ilium & 127 & 125 & 126 & 128 \\
\hline 10 & Height of iliac wing & 96 & 95 & 99 & 98 \\
\hline 11 & Depth of iliac fossa & 9 & 7 & 8 & 8 \\
\hline 12 & Width of ilium & 151 & 151 & 153 & 152 \\
\hline 13 & Width of iliac wing & 87 & 88 & 88 & 90 \\
\hline 14 & Acetab-symph. width & 119 & 118 & 121 & 122 \\
\hline 15 & Height of ischium & 83 & 81 & 82 & 81 \\
\hline 17 & Length of pubis & 82 & 79 & 83 & 82 \\
\hline 18 & Height of symphysis & 41 & 40 & 41 & 42 \\
\hline 19 & Width of symphy. region & \multicolumn{2}{|c|}{38} & \multicolumn{2}{|c|}{36} \\
\hline 20 & L. of obturator foramen & 50 & 51 & 54 & 54 \\
\hline 21 & W. of obturator foramen & 32 & 32 & 36 & 36 \\
\hline 22 & Max. diam. of acetabulum & 56 & 56 & 56 & 56 \\
\hline 23 & Sagit. diam. of pel. inlet & \multicolumn{2}{|c|}{99} & \multicolumn{2}{|c|}{100} \\
\hline 24 & Transv. diam. of pel. inlet & \multicolumn{2}{|c|}{119} & \multicolumn{2}{|c|}{124} \\
\hline 25 & Oblique diam. of pel. inlet & 116 & 116 & 118 & 120 \\
\hline 26 & Sagit. diam. of pel. outlet & \multicolumn{2}{|c|}{90} & \multicolumn{2}{|c|}{101} \\
\hline 27 & Transv. diam. of pel. outlet & & & & \\
\hline 28 & Lat. height of min. pel. & 96 & 98 & 97 & 96 \\
\hline 29 & Ant. height of min. pel. & 114 & 114 & 115 & 112 \\
\hline 30 & True height of min. pel. & 126 & 128 & 128 & 127 \\
\hline 31 & Max. width of sciatic notch & 54 & 48 & 51 & 53 \\
\hline 32 & Depth of sciatic notch & 33 & 33 & 35 & 34 \\
\hline 33 & Infra-pubic angle & & & & \\
\hline $1 / 2$ & $\mathrm{~W}-\mathrm{H}$ index & 78.9 & 78.6 & 78.7 & 77.9 \\
\hline $12 / 10$ & Iliac index & 157.3 & 158.9 & 154.5 & 155.1 \\
\hline & Patella & & & & \\
\hline 1 & Maximum height & 45 & 46 & 44 & 44 \\
\hline 2 & Maximum breadth & 51 & 52 & 49 & 50 \\
\hline 3 & Maximum thickness & 23 & 23 & 23 & 23 \\
\hline 4 & Articular height & 33 & 32 & 27 & 27 \\
\hline 5 & Breadth of medial facet & 22 & 23 & 20 & 20 \\
\hline 6 & Breadth of lateral facet & 31 & 31 & 33 & 31 \\
\hline
\end{tabular}


Table 5. Measurements (in $\mathrm{mm}$ ) and indices of the KANASEKIfamily; Femur, tibia and fibula

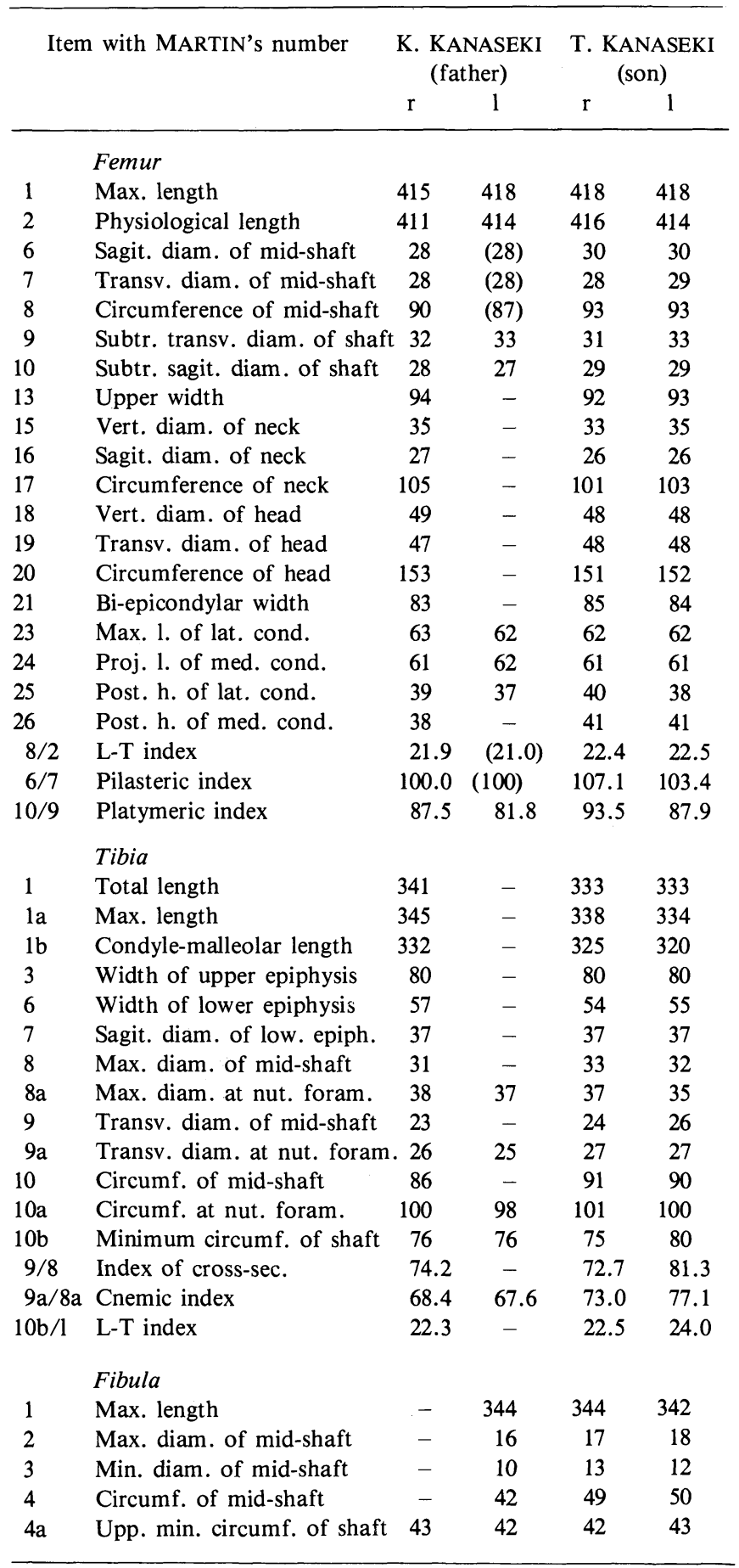


Table 5. (continued)

\begin{tabular}{|c|c|c|c|c|c|}
\hline \multicolumn{2}{|c|}{ Item with MARTIN's number } & \multicolumn{2}{|c|}{$\begin{array}{l}\text { K. KANASEKI } \\
\text { (father) }\end{array}$} & \multicolumn{2}{|c|}{$\begin{array}{c}\text { T. KANASEKI } \\
\text { (son) }\end{array}$} \\
\hline & & $\mathrm{r}$ & 1 & $\mathrm{r}$ & 1 \\
\hline $4 a^{\prime}$ & Low. min. circumf. of shaft & 44 & 44 & 44 & 44 \\
\hline $4(1)$ & Width of upper epiph. & - & 26 & 30 & 30 \\
\hline $4(2)$ & Width of lower epiph. & 23 & 23 & 21 & 21 \\
\hline $3 / 2$ & Index of cross-sec. & - & 62.5 & 76.5 & 66.7 \\
\hline $4 a / 1$ & $\mathrm{~L}-\mathrm{T}$ index & - & 12.2 & 12.2 & 12.6 \\
\hline
\end{tabular}

Table 6. Nonmetric variants in the KANASEKI-family

\begin{tabular}{|c|c|c|c|c|c|}
\hline & & \multicolumn{2}{|c|}{$\begin{array}{l}\text { K. KANASEKI } \\
\text { (father) }\end{array}$} & \multicolumn{2}{|c|}{$\begin{array}{l}\text { T. KANASEKI } \\
\text { (son) }\end{array}$} \\
\hline & & $\mathrm{r}$ & 1 & $\mathrm{r}$ & 1 \\
\hline & \multicolumn{5}{|l|}{ Cranium } \\
\hline 1 & Ossicle at the lambda & \multicolumn{2}{|c|}{-} & \multicolumn{2}{|c|}{-} \\
\hline 2 & Os Incae & \multicolumn{2}{|c|}{-} & \multicolumn{2}{|c|}{-} \\
\hline 3 & Biasterionic suture & - & - & - & - \\
\hline 4 & Sagittal groove left & \multicolumn{2}{|c|}{+} & \multicolumn{2}{|c|}{-} \\
\hline 5 & Condylar canal patent & + & + & + & + \\
\hline 6 & Hypoglossal canal bridging & - & + & + & - \\
\hline 7 & Jugular foramen bridging & - & - & - & - \\
\hline 8 & Asterionic bone & - & - & - & - \\
\hline 9 & Occipitomastoid warmians & - & - & - & - \\
\hline 10 & Pterygospinous foramen & - & - & - & - \\
\hline 11 & Foramen of HUSCHKE & - & - & - & - \\
\hline 12 & Parietal notch bone & - & - & - & - \\
\hline 13 & Metopism & \multicolumn{2}{|c|}{-} & \multicolumn{2}{|c|}{-} \\
\hline 14 & Supra-orbital foramen & + & - & - & - \\
\hline 15 & Medial palatine canal & - & - & - & - \\
\hline 16 & Transverse zygomatic suture & - & - & - & - \\
\hline 17 & Clinoid bridge & / & / & + & - \\
\hline 18 & Mandibular torus & / & / & - & - \\
\hline 19 & Mylohyoid canal & - & - & - & - \\
\hline \multirow[t]{2}{*}{20} & Supraorbital nerve groove & - & - & - & - \\
\hline & \multicolumn{5}{|l|}{ Postcranial skeleton } \\
\hline 21 & Atlas facet form double & - & - & - & - \\
\hline 22 & Atlas posterior bridge & - & - & - & - \\
\hline 23 & Atlas lateral bridge & - & - & - & - \\
\hline 24 & $\begin{array}{l}\text { Transverse foramen bipartite } \\
\text { (C3-C7) }\end{array}$ & - & - & - & - \\
\hline 25 & Sternal foramen & \multicolumn{2}{|c|}{-} & \multicolumn{2}{|c|}{-} \\
\hline 26 & Supra-scapular foramen & - & - & + & - \\
\hline 27 & Supra-condyloid process & - & - & - & - \\
\hline 28 & Septal aperture & - & - & - & - \\
\hline 29 & ALLEN's fossa & - & / & - & - \\
\hline
\end{tabular}


Table 6. (continued)

\begin{tabular}{|c|c|c|c|c|c|}
\hline & & \multicolumn{2}{|c|}{$\begin{array}{l}\text { K. KANASEKI } \\
\text { (father) }\end{array}$} & \multicolumn{2}{|c|}{$\begin{array}{l}\text { T. KANASEKI } \\
\text { (son) }\end{array}$} \\
\hline & & $\mathrm{r}$ & 1 & $\mathrm{r}$ & 1 \\
\hline 30 & Third trochanter & - & / & - & - \\
\hline 31 & Exostosis in trochanteric fossa & + & / & + & + \\
\hline 32 & Vastus notch & - & - & - & - \\
\hline 33 & Lateral tibial squatting facet & - & / & + & + \\
\hline 34 & Lateral talar extension & - & - & - & - \\
\hline 35 & Anterior calcaneal facet double & - & - & - & - \\
\hline
\end{tabular}

+ presence; - absence; / unobservable

抄録

金関家骨格の形態学的資料

土肥直美

故金関丈夫先生および御尊父の遺骨について形態 学的調查を行なったのでその資料を報告する。計測 は主として MARTIN und SALLER（1957）に従い, 顔面平坦度については YAMAGUCHI（1973，1980） に従った. また, 非計測的計質の観察は BERRY and Berry (1967), Dodo (1974, 1975), FinNEGAN （1978）を参照して行なった.

\section{References}

BERRY, A.C. and R.J. BERRY, 1967: Epigenetic variation in the human cranium. J. Anat., 101: 361-379. DoDO, Y., 1974: Non-metrical cranial traits in the
Hokkaido Ainu and the northern Japanese of recent times. J. Anthrop. Soc. Nippon, 82: 31-51.

DoDO, Y., 1975: Non-metric traits in the Japanese crania of the Edo period. Bull. Natn. Sci. Mus. Tokyo, Ser. D, 1: 41-54.

FINNEGAN, M., 1978: Non-metric variation of the infracranial skeleton. J. Anat., 125: 23-37.

KANASEKI, T., 1966: People of the Yayoi period. In: Nippon no Kokogaku, III. Kawade Shobo, Tokyo, pp. 460-471. (In Japanese)

[金関丈夫, 1966 : 弥生時代人. 日本の考古学 III. 弥生時代. 河出書房, 東京, pp, 460-471]

MARTIN, R. und K. SALlER, 1957: Lehrbuch der Anthropologie. Bd. I. G. Fischer, Stuttgart.

YAMAGUCHI, B., 1973: Facial flatness measurements of the Ainu and Japanese crania. Bull. Natn. Sci. Mus. Tokyo, 16: 161-171.

YAMAGUCHI, B., 1980: A study of the facial flatness of the Jomon crania. Bull. Natn. Sci. Mus. Tokyo, Ser. D, 6: 21-28. 

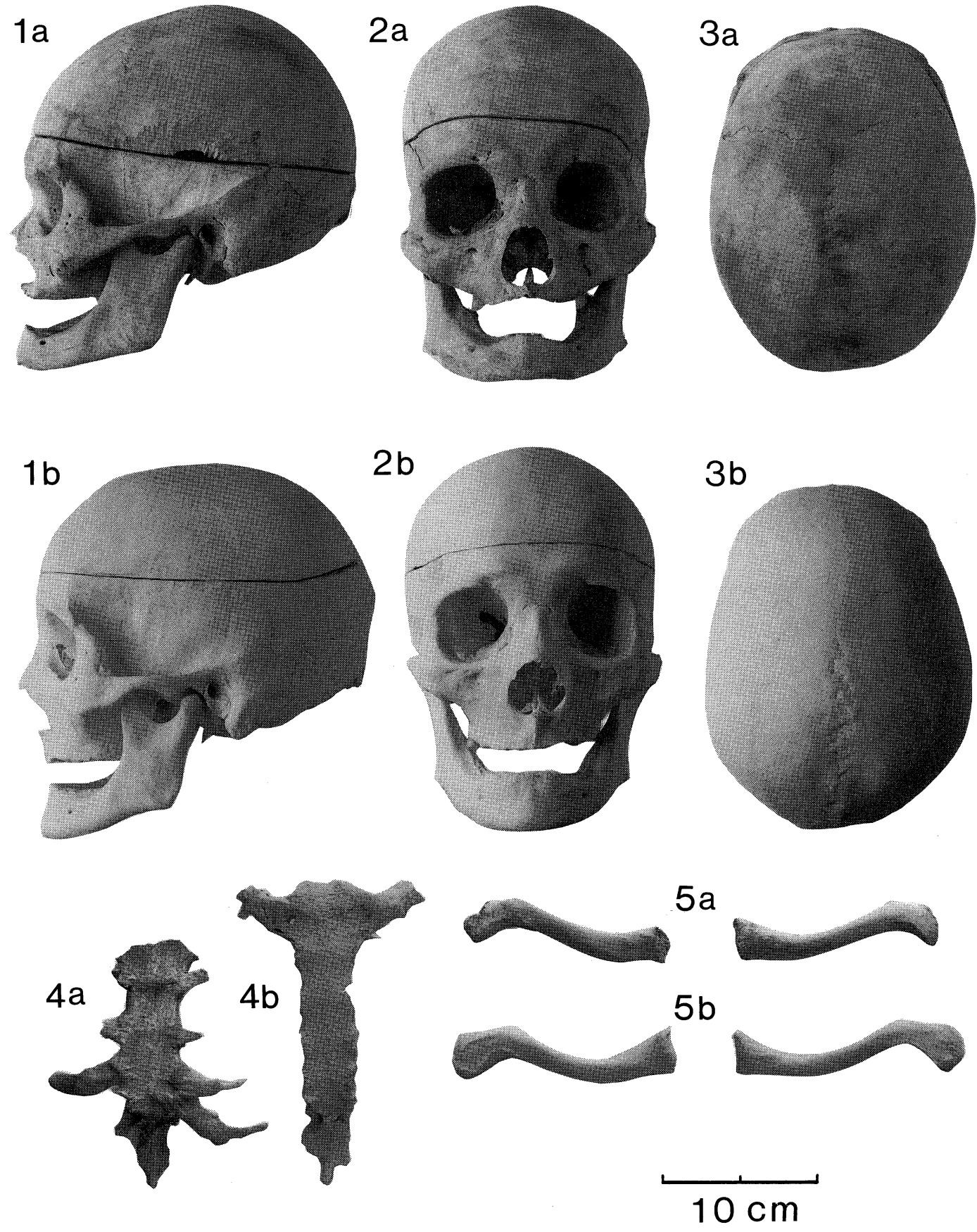

Plate 1. Skeletons of Mr. K. KANASEKI (a) and Dr. T. KANASEKI (b). 1: left lateral view of the skull. 2: frontal view of the skull. 3: superior view of the skull. 4: frontal view of the sternum. 5: superior view of the clavicle. 

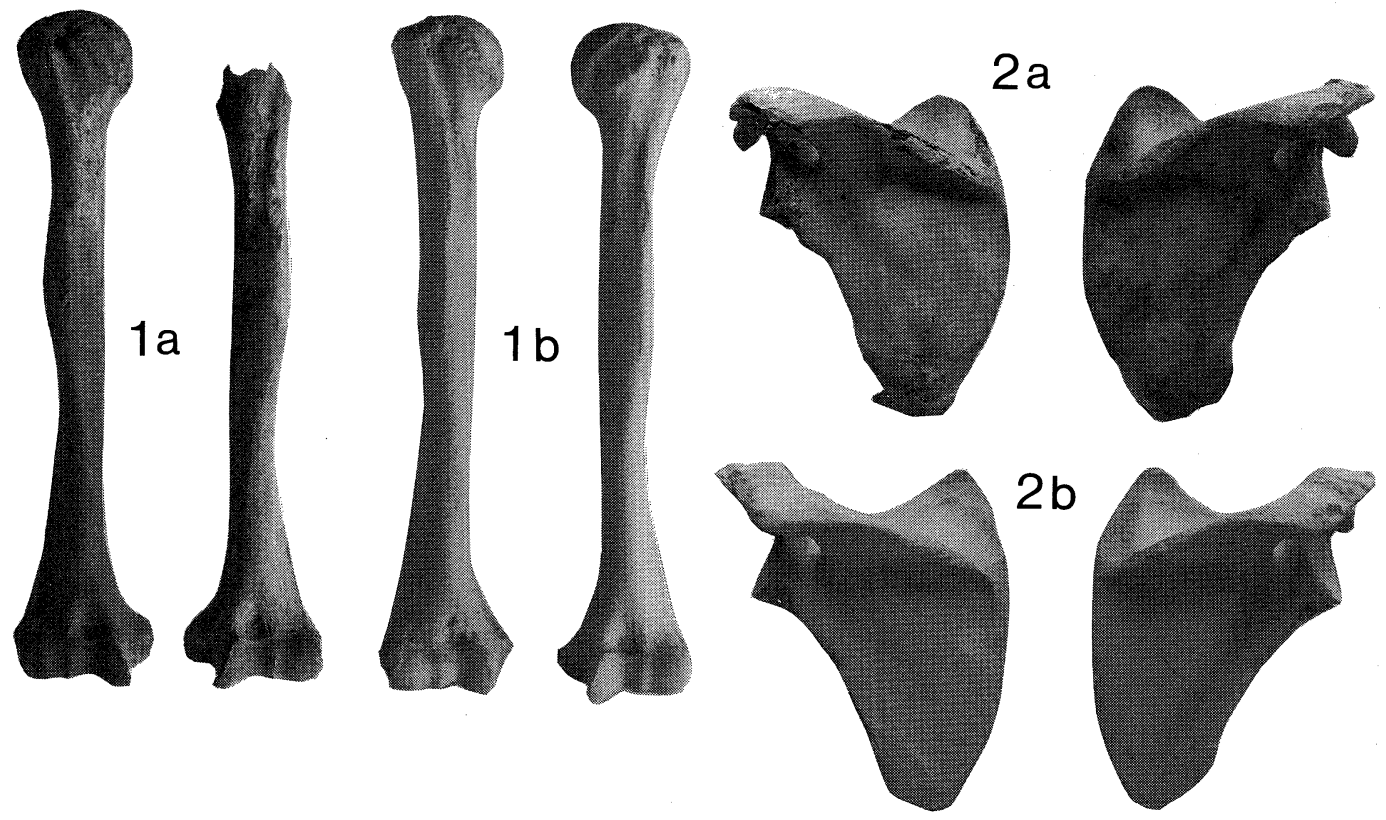

$3 a$

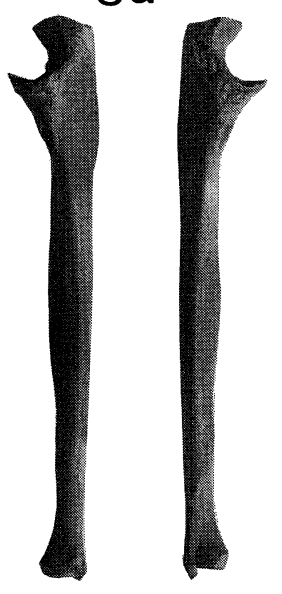

$3 b$
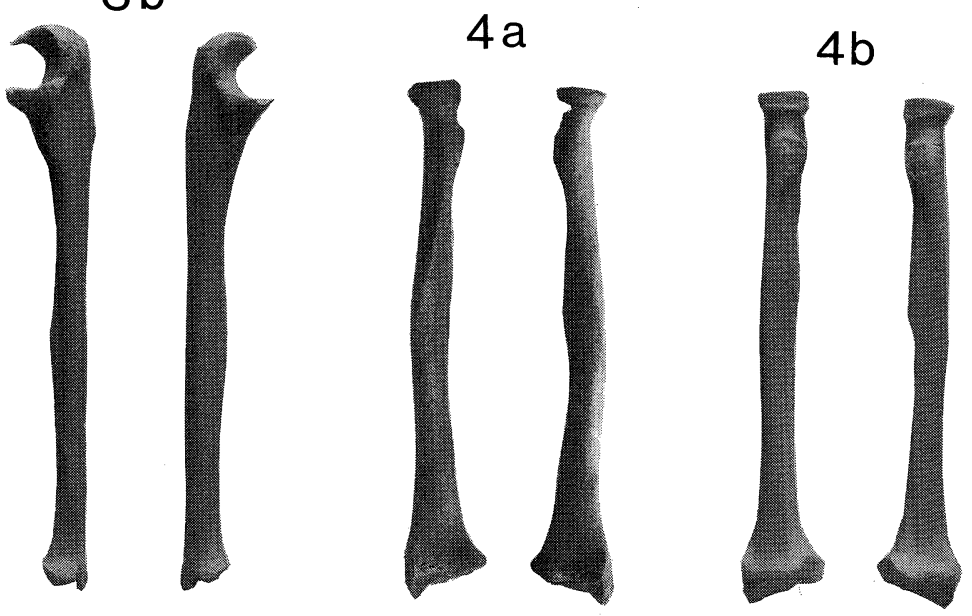

$10 \mathrm{~cm}$

Plate 2. Skeletons of Mr. K. KANASEKI (a) and Dr. T. KANASEKI (b). 1: anterior view of the humerus. 2: posterior view of the scapula. 3: anterior view of the ulna. 4: anterior view of the radius. 

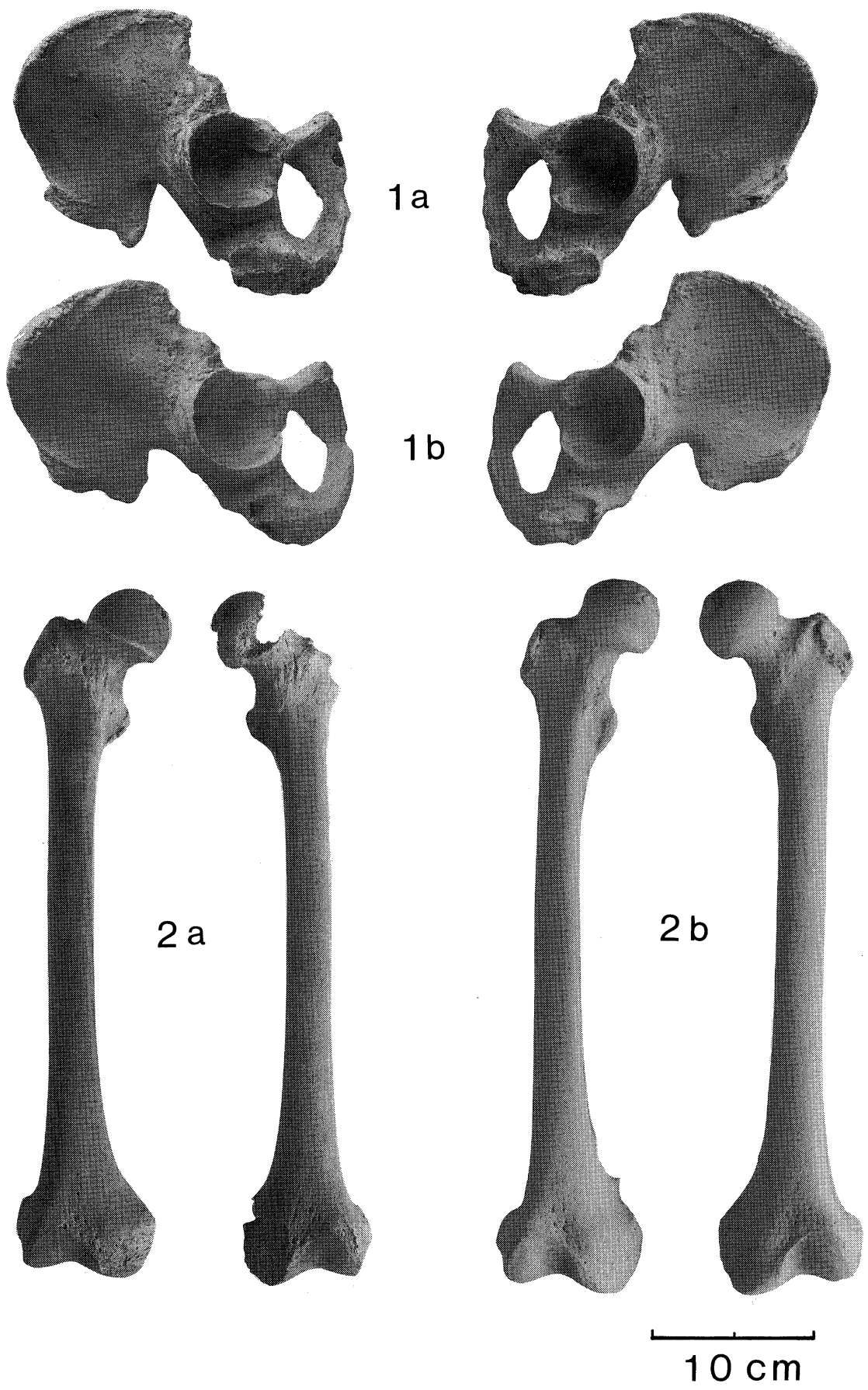

Plate 3. Skeletons of Mr. K. KANASEKI (a) and Dr. T. KANASEKI (b). 1: lateral view of the innominate bone. 2: anterior view of the femur. 

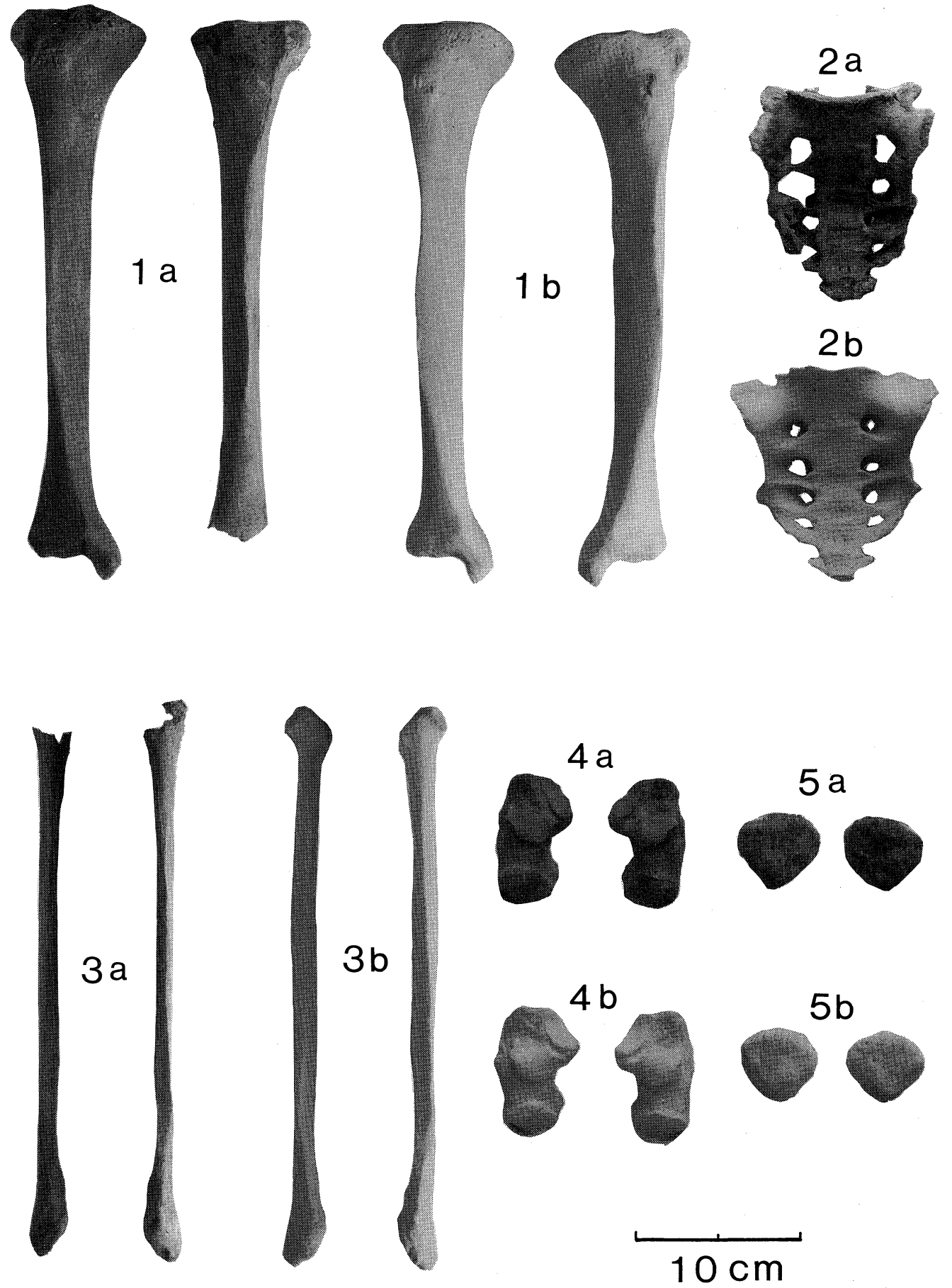

Plate 4. Skeletons of Mr. K. KANASEKI (a) and Dr. T. KANASEKI (b). 1: anterior view of the tibia. 2: anterior view of the sacrum. 3: anterior view of the fibula. 4: superior view of the calcaneus. 5: anterior view of the patella. 


\section{土 肥 直 美 九州大学医学部解剖学第 2 講座 \\ T812 福岡市東区馬出 3-1-1}

Naomi DoI

Department of Anatomy, Faculty of Medicine, Kyushu University

3-1-1 Maidashi, Higashi-ku, Fukuoka 812, Japan 